\title{
Reorientasi civic disposition dalam kurikulum Pendidikan Kewarganegaraan sebagai upaya membentuk warga negara yang ideal
}

\author{
Budi Mulyono \\ Universitas Negeri Yogyakrta \\ budi.mulyono@uny.ac.id
}

\begin{abstract}
This article discusses the urgency of civic disposition in citizenship education curriculum in order to shape citizen character. Civic disposition is a the most substantive and essential element of citizenship education. In this matter it is intended that good citizen is the target. But, in the course of time, it is evidenced that citizenship education curriculum is intervened by rezim. The feature of a good citizenship means differently to different rezim. It is recommended that the reoriented of this curriculum is intended to release the interest and power of rezim by placing Pancasila and 1945 Constitution.
\end{abstract}

Keywords: civic disposition, civic education, good citizen, student

\section{Pendahuluan}

Setiap bangsa dan negara mengakui pentingnya pembangunan karakter bangsa (national character building) dalam rangka memelihara dan mempertahankan eksistensi sebagai suatu bangsa-negara (nation-state). Untuk membentuk karakter warga negara yang baik (good citizens) tidak bisa dilepaskan dari pendidikan. Pendidikan sangat berperan dalam membentuk baik atau buruknya pribadi manusia menurut ukuran normatif. Dalam Undang-Undang No. 20 Tahun 2003 tentang Sistem Pendidikan Nasional disebutkan bahwa sistem pendidikan nasional berfungsi untuk mengembangkan kemampuan dan membentuk watak serta peradaban bangsa yang bermartabat dalam rangka mencerdaskan kehidupan bangsa, bertujuan untuk berkembangnya potensi peserta didik agar menjadi manusia yang beriman dan bertakwa kepada Tuhan Yang Maha Esa, berakhlak mulia, sehat, berilmu, cakap, kreatif, mandiri, dan menjadi warga negara yang demokratis serta bertanggung jawab (Pasal 3 UU No 20 Tahun 2003).
Salah satu pelajaran yang mengemban misi membangun karakter warga negara yang baik adalah Pendidikan Kewarganegaraan (PKn). Pendidikan Kewarganegaraan atau civics education mengemban misi untuk membentuk siswa agar kelak menjadi warga masyarakat sekaligus warga negara yang cerdas, terampil dan berwatak sebagai penjamin keberlangsungan bangsa dan negara. Pada tataran kurikuler PKn baik substansi, proses pembelajaran, maupun efek sosio-kulturalnya, sengaja dirancang dan diprogramkan untuk mewujudkan programprogram pendidikan demokrasi yang bermuara pada pembentukan karakter bangsa Indonesia.

Branson (1999, pp. 8-25) menegaskan PKn dalam menghadapi era globalisasi hendaknya mengembangkan kompetensi kewarganegaraan (civic competences). Di antara aspek-aspek civic competences tersebut meliputi pengetahuan kewarganegaraan (civic knowledge), keterampilan kewarganegaraan (civic skill), dan watak atau karakter kewarganegaraan (civic disposition) sehingga dapat 
menumbuhkan karakter warga negara yang baik.

Tujuan utama dari civic disposition adalah untuk menumbuhkan karakter warga negara, baik karakter privat seperti; tanggungjawab moral, disiplin diri, dan penghargaan terhadap harkat dan martabat manusia dari setiap individu, maupun karakter publik misalnya; kepedulian sebagai warga, kesopanan, mengindahkan aturan main (rule of law), berpikir kritis, dan kemauan untuk mendengar, bernegosiasi dan kompromi (Branson, 1999, p. 23). Pertanyaannya, bagaimana peran PKn dalam membentuk karakter bangsa baik di sekolah maupun di luar sekolah?

Sebagai program pendidikan, PKn memiliki lingkup yang cukup luas dan meliputi setidaknya tiga domain dalam proses pembentukan karakter, yakni (1) secara konseptual PKn berperan dalam mengembangkan konsep-konsep dan teori; (2) secara kurikuler PKn mengembangkan sejumlah program pendidikan dan model implementasinya dalam mempersiapkan peserta didik menjadi manusia dewasa yang berkarakter melalui lembaga-lembaga pendidikan; dan (3) secara sosio kultural PKn melaksanakan proses pembelajaran kepada masyarakat agar menjadi warga negara yang baik (Sapriya, 2007: 5)

Dengan demikian, tidak diragukan lagi jika PKn memiliki kedudukan yang sangat strategis dalam "national character building". Akan tetapi, dalam pelaksanaannya PKn sangat rentan terhadap bias politik penguasa (the rolling class) sehingga cenderung lebih merupakan instrumen penguasa daripada sebagai wahana pembangunan watak bangsa berdasarkan konstitusi. Perubahan nama yang selalu berganti seiring dengan pergantian rezim mengindikasikan secara kuat bahwa kepentingan rezim tidak bisa lepas dari Pendidikan Kewarganegaraan (civic education) sebagai pembentuk karakter warga negara. Tidak hanya dalam penamaan dari civics education yang mengalami tekanan dari rezim, melainkan isi (content) dari Pendidikan Kewarganegaraan juga kerap "dititipi" nilai-nilai yang hendak diwujudkan melalui pendidikan kewarganegaraan. Yang perlu ditanyakan di sini adalah, bagaimana kebijakan pendidikan sebagai kebijakan publik bisa dipengaruhi oleh faktor-faktor politik rezim sehingga kebijakan pendidikan menjadi tidak netral. Upaya membentuk warga negara yang ideal berubah haluan menjadi membentuk warga negara yang tunduk dan patuh untuk mempertahankan status quo.

Hilangnya karakter kewarganegaraan memunculkan sikap egois dan fundamentalis yang berujung pada aksi kriminal yang dilakukan oleh remaja sekolah. Krisis karakter kewarganegaraan sudah waktunya untuk diatasi secara struktural oleh bangsa Indonesia. Di samping itu, peran lembaga pendidikan maupun para stakeholder di bidang pendidikan diharapkan lebih proaktif, kreatif dan inovatif dalam merancang proses pembelajaran yang benar-benar mampu memberikan kontribusi bagi pembangunan pendidikan karakter terutama karakter kewarganegaraan. Dalam konteks inilah proses pendidikan karakter perlu dirancang dalam perspektif holistik dan kontekstual sehingga mampu membangun pemikiran yang dialogis-kritis dalam membentuk manusia yang berkarakter, dalam semua level masyarakat yakni keluarga, sekolah, masyarakat dan negara. 


\section{Deskripsi civic disposition}

Civic disposition merupakan salah satu kompetensi kewarganegaraan Pendidikan Kewarganegaraan (civic competences) yang disampaikan oleh Branson (1999, p. 8-25) yang meliputi pengetahuan kewarganegaraan (civic knowledge), keterampilan kewarganegaraan (civic skill), dan watak atau karakter kewarganegaraan (civic disposition) sehingga dapat menumbuhkan karakter warganegara yang baik.

Civic knowledge berkaitan dengan materi substansi yang seharusnya diketahui oleh warga negara berkaitan dengan hak dan kewajibannya sebagai warga negara. Aspek dari civic knowledge ini menyangkut kemampuan akademik-keilmuan yang dikembangkan dari berbagai teori atau konsep politik, hukum dan moral. Sedangkan civics skill atau kecakapan kewarganegaraan merupakan kecakapan yang dikembangkan dari pengetahuan kewarganegaraan, yang dimaksudkan agar pengetahuan yang diperoleh menjadi sesuatu yang bermakna, karena dapat dimanfaatkan dalam menghadapi masalah-masalah kehidupan berbangsa dan bernegara. Kecakapan kewarganegaraan meliputi kecakapankecakapan intelektual (intellectual skills) dan kecakapan partisipasi (participation skills) (Branson, 1999, pp. 8-20).

\section{Sedangkan civic disposition} sesungguhnya merupakan kompetensi yang paling substantif dan esensial dalam mata pelajaran PKn. Kompetensi watak kewarganegaraan dapat dipandang sebagai "muara" dari pengembangan kedua kompetensi sebelumnya. Dalam deskripsinya Quigley, dkk (1991: 11) menyebut civics disposition sebagai “...those attitudes and habit of mind of the citizen that are conducive to the healthy functioning and common good of the democratic system" atau "sikap dan kebiasaan berpikir warga negara yang menopang berkembangnya fungsi sosial yang sehat dan jaminan kepentingan umum dari sistem demokrasi”. Civics disposition mengisyaratkan pada karakter publik maupun privat yang penting bagi pemeliharaan dan pengembangan demokrasi konstitusional (Branson, 1999, p. 23).

Watak kewarganegaraan sebagaimana kecakapan kewarganegaraan, berkembang secara perlahan sebagai akibat dari apa yang telah dipelajari dan dialami oleh seseorang di rumah, sekolah, komunitas, dan organisasiorganisasi civil society. Pengalamanpengalaman demikian hendaknya membangkitkan pemahaman bahwasanya demokrasi mensyaratkan adanya pemerintahan mandiri yang bertanggung jawab dari tiap individu. Karakter privat seperti bertanggung jawab, moral, disiplin diri, dan penghargaan terhadap harkat dan martabat manusia dari setiap individu adalah wajib. Karakter publik juga tidak kalah penting. Kepedulian sebagai warga negara, kesopanan, mengindahkan aturan main (rule of law), berpikir kritis, dan kemauan untuk mendengar, bernegosiasi dan berkompromi merupakan karakter yang sangat diperlukan agar demokrasi berjalan sukses.

Secara ringkas karakter publik dan privat sebagaimana disampaikan oleh Branson (1999: 23-25) dapat dijabarkan sebagai berikut.

1) Menjadi anggota masyarakat yang independen.

2) Memenuhi tanggung jawab personal kewarganegaraan di bidang ekonomi dan politik.

3) Menghormati harkat dan martabat kemanusiaan tiap individu.

4) Berpartisipasi dalam urusan-urusan kewarganegaraan secara efektif dan bijaksana. 
5) Mengembangkan berfungsinya demokrasi konstitusional secara sehat.

\section{Urgensi Civic Disposition dalam} Membentuk Warga Negara Yang Ideal

Dalam rentang sejarah penerapan kurikulum Pendidikan Kewarganegaraan baik pada masa pemerintahan Orde Lama, Orde Baru, maupun Reformasi, kesemuanya memiliki tujuan yang sama dalam membentuk civics disposition yaitu bagaimana membentuk karakter warga negara yang baik. Akan tetapi, upaya membentuk karakter warga negara yang baik ini sering tidak pernah lepas dari kepentingan pemerintahan yang berkuasa. Yang menjadi permasalahan adalah ketika definisi warga negara yang baik adalah warga negara yang tunduk pada rezim yang sedang berkuasa. Dari sinilah titik awal kepentingan-kepentingan politik rezim masuk dan berusaha memanfaatkan kurikulum Pendidikan Kewarganegaraan untuk menitipkan kepentingan-kepentingannya, dengan pendekatan indoktrinatif dan menempatkan warga negara sebagai subjek yang patuh. Kecurigaan yang sama juga disampaikan oleh Reynolds bahwa the question, thus, is whether a particular approach to civic education is preparing citizens to be obedient subjects, or preparing them to be responsible rulers. This is a question that cannot be answered simply by looking at the nominal form of the government, since even in a representative democracy, government officials tendalways for the highest possible motives, of course-to want to accumulate power to themselves, while minimizing their accountability to the Great Unwashed. Such is human nature, and few indeed are the politicians who can rise above it. That being the case, the citizenry-and particularly that portion of the citizenry composed of parents and students - must be particularly vigilant to ensure that civic education doesn't become just another tool for keeping the powers that be in being (2011, p. 204).

Maksud dari Glenn Harlan Reynolds tersebut adalah: Pertanyaannya, dengan demikian, apakah pendekatan tertentu dalam Pendidikan Kewarganegaraan adalah untuk mempersiapkan warga negara menjadi subjek yang patuh, atau mempersiapkan mereka untuk menjadi penguasa yang bertanggung jawab. Ini adalah pertanyaan yang tidak bisa dijawab hanya dengan melihat bentuk fisik pemerintahan saja, karena bahkan dalam demokrasi perwakilan, kekuasaan pemerintah cenderung-selalu demi alasan yang tidak pasti, yaitu tentu saja-ingin mengakumulasi kekuasaan untuk diri mereka sendiri, sementara di sisi lain meminimalkan tanggung jawab mereka kepada masyarakat kelas bawah. Itulah sifat manusia, dan sedikit memang politisi yang bisa menahan diri dari hal tersebut. Itulah yang terjadi, warga negara-dan khususnya bahwa sebagian dari warga yang terdiri dari orang tua dan siswaharus sangat waspada untuk memastikan bahwa Pendidikan Kewarganegaraan tidak menjadi hanya alat lain untuk menjaga kekuasaan yang ada.

Peringatan dari Glenn Harlan Reynolds tersebut seharusnya menjadi catatan bagi para para praktisi dan akademisi Pendidikan Kewarganegaraan akan potensi yang mungkin akan selalu berulang, bahwa Pendidikan Kewarganegaraan menjadi alat kekuasaan. Pengalaman sejarah telah menunjukkan hal itu. Pada saat kurikulum era Orde Lama dengan nomenklatur Civics (1962) ingin membentuk karakter warga negara yang "sosialis Indonesia yang susila" yang merujuk pada Keputusan Presiden No. 145 tahun 1965 yang merumuskan tujuan nasional pendidikan sebagai berikut yakni: 
tujuan pendidikan Nasional kita baik yang diselenggarakan oleh pihak Pemerintah maupun oleh pihak swasta, dari pendidikan Pra-sekolah sampai pendidikan tinggi, supaya melahirkan warganegara-warganegara Sosialis Indonesia yang susila, yang bertanggungjawab atas terselenggaranya Masyarakat Sosialis Indonesia, Adil dan Makmur baik Spiritual maupun material dan yang berjiwa Pancasila yaitu: (a) Ke-Tuhanan Jang maha Esa, (b) Kemanusiaan jang adil dan beradab, (c) Kebangsaan, (d) Kerakyatan, (e) Keadilan sosial, Seperti dijelaskan dalam Manipol-USDEK (Keppres RI No. 145 Tahun 1965).

Kebijakan tersebut dibuat untuk menjaga agar arah pendidikan tidak menuju ke pembentukan manusia liberal yang dianggap sangat bertentangan dengan jiwa dan semangat bangsa Indonesia. Pada masa Orde Lama Pancasila memang menjadi asas pendidikan tetapi Pancasila telah direduksi dalam Manipol-USDEK yang digunakan oleh Orde Lama untuk mempertahankan kekuasaannya.

Setali tiga uang, Pendidikan Kewarganegaraan pada masa Orde Baru juga mengalami nasib yang serupa. Meski hadir dengan beragam nomenklatur, dari Pendidikan Kewargaan Negara (1968), PMP (1975 dan 1984), dan PPKn (1994) kurikulum Pendidikan Kewarganegaraan menjadi instrumen yang sangat efektif dalam menerjemahkan nilai-nilai Orde Baru yang ingin membentuk "manusia pembangunan yang Pancasilais". Pancasila yang menjadi core value dari Pendidikan Kewarganegaraan juga telah direduksi menjadi 36 butir yang terangkum dalam P4.

Kurikulum

Pendidikan

Kewarganegaraan pada masa Reformasi hadir dengan paradigma baru. Dengan mengusung nomenklatur Pendidikan Kewarganegaraan (PKn) pada kurikulum 2004 dan 2006 serta Pendidikan Pancasila dan Kewarganegaraan (PPKn) dalam kurikulum 2013 ingin membentuk warga negara yang "kritis, demokratis, dan partisipatif'. Akan tetapi, Pendidikan Kewarganegaraan paradigma baru yang mengadopsi dari Center for Civic Education (CCE) Amerika Serikat, dikritik sangat liberal.

Melihat berbagai perjalanan kurikulum Pendidikan Kewarganegaraan dari era pemerintahan Orde Lama, Orde Baru, dan Reformasi, terdapat satu titik sentral yang sama, yaitu menempatkan Pancasila sebagai core value dalam pelajaran Pendidikan Kewarganegaraan untuk membentuk karakter warga negara yang diidealkan. Akan tetapi, Pancasila dalam berbagai rezim tersebut menjelma menjadi beberapa tafsiran yang berbeda-beda. Perbedaan cara memandang Pancasila dan nilai-nilainya ini sesuai dengan kehendak penguasa yang memiliki kecenderungan berusaha mengakumulasi kekuasaan sebagaimana telah diulas oleh Glenn Harlan Reynolds sebelumnya.

Berbagai analisis tersebut di atas, memberi gambaran bahwa ternyata untuk membangun karakter warga negara yang berdasarkan Pancasila itu tidaklah mudah. Sangat banyak faktor yang mempengaruhi proses Pendidikan Kewarganegaraan itu sendiri. Maka dari itu perlu dilakukan reorientasi civics disposition dalam kurikulum Pendidikan Kewarganegaraan untuk "memurnikan" tujuan pembentukan karakter warga negara yang baik. Agar terlepas dari kepentingan politik rezim yang singkat, tetapi beralih pada politik negara yang lebih abadi. Untuk mewujudkannya dibutuhkan budaya kewarganegaraan (civic culture) untuk membentuk karakter warga 
negara yang diidealkan. Salah satu unsur dari budaya kewarganegaraan adalah "civic virtue" atau kebajikan kewarganegaraan yang terpancar dari nilai-nilai Pancasila mencakup keterlibatan aktif warga negara, hubungan kesejajaran/egaliter, saling percaya dan toleran, kehidupan yang kooperatif, solidaritas, dan semangat kemasyarakatan. Semua unsur karakter kewarganegaraan itu diyakini akan saling memupuk dengan kehidupan "civic community" atau "civil society" atau masyarakat madani untuk Indonesia yang berdasarkan Pancasila.

\section{Membentuk Kurikulum Pendidikan Kewarganegaraan yang Ideal}

Karakter kewarganegaraan atau civic disposition telah menjadi bagian tidak terpisahkan dalam pembelajaran pendidikan kewarganegaraan. Meskipun dalam rentetan sejarahnya, karakter kewarganegaraan terjadi bias makna karena selalu mendapat intervensi kekuasaan dalam penerapannya dalam kurikulum khususnya kurikulum pendidikan kewarganegaraan. Untuk itu dibutuhkan pembentukan kurikulum Pendidikan Kewarganegaraan lebih independen dan tentunya konstruktif dalam membentuk karakter warga negara yang ideal yaitu warganegara yang kritis, partisipatoris, dan demokratis. Akan tetapi, karakter publik dan privat yang ditanamkan oleh kurikulum Pendidikan Kewarganegaraan kepada siswa tersebut tidak bisa ditanamkan dengan cara yang indoktrinatif dan penuh dengan pesanpesan penguasa yang akan mempertahankan kekuasaannya. Kurikulum Pendidikan Kewarganegaraan dalam membentuk karakter kewarganegaraan sebaiknya dikembangkan dengan cara berpikir kritis sehingga peserta didik tidak menelan secara mentah-mentah pesan-pesan yang ada di dalamnya. Kurikulum Pendidikan Kewarganegaraan seharusnya mengembangkan kemampuan siswa untuk mengevaluasi cara pandang alternatif terhadap kepentingan bersama dan kepentingan pribadi dan untuk menentukan kebijakan dan kandidat publik mana yang paling sesuai untuk melayani mereka. Siswa harus diajarkan untuk menilai secara kritis (dan tidak menelan mentah-mentah) pesanpesan politik yang mengklaim berbicara atas nama kepentingan mereka dan melayani kepentingan publik (Quigley \& Bahmueller, 2011, p. 128).

Dengan mendasarkan pada Pancasila dan konstitusi negara, UUD 1945, akan menjauhkan Pendidikan Kewarganegaraan dari kepentingan sesaat penguasa. Pengalaman bertahun-tahun di bawah kepemimpinan rezim Orde Lama dan Orde Baru dengan alternatif tafsir Pancasila seperti Manipol-USDEK dan P4 telah menjadikan Pendidikan Kewarganegaraan jauh dari kepentingan akademik, justru dekat dengan kepentingan penguasa untuk mempertahankan kekuasaannya. Untuk itu, ke depan perlu ditanamkan sikap kritis dan bertanggungjawab agar karakter kewarganegaraan yang terbentuk bukan karakter yang tunduk dan bukan pula anarkis. Maksud semua hal tersebut adalah bagaimana membentuk warga negara ideal sebagaimana diinginkan yang dalam konteks Indonesia harus ditempatkan dalam konteks nilai-nilai Pancasila dan UUD 1945. Oleh karena itu, Pendidikan Kewarganegaraan merupakan program pembelajaran nilai dan moral Pancasila dan UUD 1945 yang bermuara pada terbentuknya watak Pancasila dan UUD 1945 dalam diri peserta didik. Karakter/watak ini pembentukannya harus dirancang sedemikian rupa sehingga terjadi keterpaduan konsep moral, sikap moral dan perilaku moral Pancasila dan UUD 1945. 
Contoh sikap ini, sebagaimana disampaikan oleh Sapriya (2007, p. 30), bahwa ada tiga paradigma pengembangan yang disebut pula sebagai concentric paradigm. Pertama, adalah Pendidikan Kewarganegaraan sebagai educational about democracy. Strategi ini bertujuan agar warga negara mengenal atau tahu konsep demokrasi dengan segala lika-likunya. Kedua, adalah Pendidikan Kewarganegaraan sebagai education through democracy. Melalui paradigma ini warga negara belajar bukan sekadar mengenal atau tahu demokrasi, melainkan belajar atau berlatih mempraktekkan atau berbuat secara demokratis. Ketiga, adalah Pendidikan Kewarganegaraan sebagai educational for democracy maksudnya adalah Pendidikan Kewarganegaraan bukan hanya sekadar mendidik orang agar tahu tentang demokrasi dan bisa berbuat secara demokratis, tetapi mampu membangun komitmen untuk membangun demokrasi. Inilah karakter warga negara yang dicita-citakan. Yaitu warga negara yang tidak hanya tau dan bisa berbuat secara demokratis, tetapi mampu membangun komitmen untuk membangun demokrasi. Dengan demikian, warga negara yang dihasilkan adalah warga negara yang cerdas, dan baik yakni memiliki moral knowing, moral feeling, dan moral action (behavior).

\section{Simpulan}

Berdasarkan uraian tersebut, dapat disimpulkan bahwa Pendidikan Kewarganegaraan memiliki peranan yang sangat sentral dalam pembentukan karakter warga negara yang baik. Pembentukan karakter warga negara menjadi bagian dari kompetensi kewarganegaraan yang meliputi pengetahuan kewarganegaraan (civic knowledge), keterampilan kewarganegaraan (civic skill), dan watak atau karakter kewarganegaraan (civic disposition) sehingga dapat menumbuhkan karakter warganegara yang baik (Branson 1999: 8-25). civic disposition sesungguhnya merupakan kompetensi yang paling substantif dan esensial dalam mata pelajaran PKn. Kompetensi watak kewarganegaraan dapat dipandang sebagai "muara" dari pengembangan kedua kompetensi sebelumnya.

Dalam sejarahnya, intervensi kepentingan rezim penguasa sangat kentara dalam kurikulum Pendidikan Kewarganegaraan baik sejak era orde lama maupun orde baru. Untuk itu reorientasi civic disposition dalam kurikulum Pendidikan Kewarganegaraan untuk "memurnikan" tujun pembentukan karakter warga negara yang baik tidak terelakkan lagi. Tujuannya adalah agar Pendidikan Kewarganegaraan terlepas dari kepentingan politik rezim yang singkat, tetapi beralih pada politik negara yang lebih abadi. Untuk mewujudkannya dibutuhkan budaya kewarganegaraan (civic culture) untuk membentuk karakter warga negara yang diidealkan. Salah satu unsur dari budaya kewarganegaraan adalah "civic virtue" atau kebajikan kewarganegaraan yang terpancar dari nilai-nilai Pancasila mencakup keterlibatan aktif warga negara, hubungan kesejajaran/egaliter, saling percaya dan toleran, kehidupan yang kooperatif, solidaritas, dan semangat kemasyarakatan.

Dengan demikian, untuk membentuk warga negara yang ideal sebagaimana diinginkan dalam konteks Indonesia harus ditempatkan dalam konteks nilai-nilai Pancasila dan UUD 1945. Oleh karena itu, Pendidikan Kewarganegaraan merupakan program pembelajaran nilai dan moral Pancasila dan UUD 1945 yang bermuara pada 
terbentuknya watak Pancasila dan UUD 1945 dalam diri peserta didik.

\section{Daftar Pustaka}

Branson, M.S. (Eds). (1999). Belajar civic education dari Amerika. (Terjemahan Syarifudin, dkk) Yogyakarta: Lembaga Kajian Islam dan Sosial (LKIS) dan The Asia Foundation (TAF).

Quigley, Charles N. \& Bahmueller, Charles F. (2011) Teaching Political Sophistication: On Self-Interest and the Common Good. Dalam David Feith. (2011). dalam Teaching America: the case for civic education.New York: Rowman \& Littlefield Publishers, Inc.

Quigley, C.N., Buchanan, Jr. J. H. \& Bahmueller, C.F. (1991). CIVITAS: a frame work for civic education. Calabasas: Center for Civic Education.

Sapriya. (2007). Peran Pendidikan Kewarganegaraan dalam membangun karakter warga negara. Dalam Jurnal Sekolah Dasar. Tahun 16, Nomor I, Mei 2007.

Reynolds, Glenn Harlan. (2011). Education versus indoctrination. Dalam David Feith. (2011). dalam Teaching America: the case for civic education. New York: Rowman \& Littlefield Publishers, Inc.

Keputusan Presiden Republik Indonesia No. 145 Tahun 1965 tentang, Nama dan Rumusan Induk Sistem Pendidikan Nasional Pancasila.

Undang-Undang No. 20 Tahun 2003, tentang Sistem Pendidikan Nasional.

Undang-undang Dasar Negara Republik Indonesia Tahun 1945 